\title{
The Differences in Transaminase Enzyme Levels among Children with Acute Diarrhea due to Rotavirus and Non-rotavirus
}

\author{
Samitha Wijaya ${ }^{1}$ D, I Putu Gede Karyana ${ }^{1 *}$, Eka Gunawijaya ${ }^{1}$, Ida Bagus Subanada ${ }^{1}$, I Gusti Agung Ngurah Sugitha Adnyana , \\ Komang Ayu Witarini ${ }^{2}$ \\ ${ }^{1}$ Department of Child Health, Medical Faculty of Udayana University, Sanglah Hospital, Denpasar, Indonesia; ${ }^{2}$ Department of \\ Child Health, Medical Faculty of Udayana University, Udayana Hospital, Badung, Indonesia
}

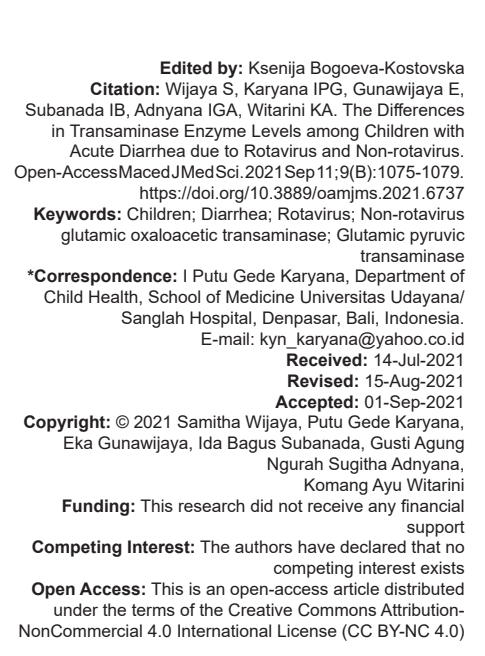

\begin{abstract}
BACKGROUND: Diarrhea is the particular disease that still affects children in Indonesia, with rotavirus being the most common etiology among children under 5 years old. Rotavirus and non-rotavirus diarrhea can spread to the extraintestinal and localized to the liver which causes liver cell damage, thus, the level of the glutamic oxaloacetic and glutamic pyruvic transaminase enzymes increases.

AIM: The objective of the study was to prove that there are differences in serum levels of glutamic oxaloacetic and glutamic pyruvic transaminase in children with acute diarrhea due to rotavirus and non-rotavirus infection.

METHODS: This study used a cross-sectional design, the research subjects were children aged 6 months old unti 60 months old with acute diarrhea in Denpasar Public Health Center, Sanglah, and Wangaya General Hospital within the period of March 2018 until March 2021. Statistical analysis used the Mann-Whitney.

RESULTS: A total of 70 subjects were analyzed in this study. There were $24.28 \%$ of subjects with rotavirus. Each group had nearly the same degree of severity of $29.4 \%$ for rotavirus and $30.2 \%$ for non-rotavirus, with a median of serum levels of glutamic oxaloacetic transaminase (SGOT) 47 (19-261) and glutamic pyruvic transaminase (SGPT) $25(7-217)$. The results of this study showed that the median difference in aspartate aminotransferase and alanine aminotransferase levels was not significant in rotavirus and non-rotavirus diarrhea (SGOT 45 [16-168], 32 [11-261], $p=0.077 ;$ (SGPT 22 [14-91], 18 [5-217], $p=0.12$ ).

CONCLUSION: This study concluded that there is a higher median level of SGOT and SGPT in children with acute diarrhea due to rotavirus infection compared to non-rotavirus infection, although it is not statistically significant.
\end{abstract}

\section{Introduction}

Transaminase enzyme is one of the enzyme markers of liver damage. The elevated transaminase enzyme levels can be caused by an autoimmune process, metabolic, prolonged drug consumption, anatomical abnormalities, and circulatory disorders in the liver and infection processes, one of which is diarrhea. In the children with diarrhea, extraintestinal processes can occur, one of which is the spreading of the infection to the liver, which is characterized by an increase in the transaminase enzyme levels.

Diarrhea is one of the most common diseases suffered by children in Indonesia. The most common cause of diarrhea in children under 5 years old is rotavirus infection. The diarrhea that has been most studied for its extraintestinal spread, especially to the liver, is diarrhea due to rotavirus. The spreading process of rotavirus to the liver is related to the severity of the diarrhea suffered by children. The infection process in the liver causes liver cell damage so that the serum levels of glutamic oxaloacetic transaminase and glutamic pyruvic transaminase increase. Non- rotaviral diarrhea can also spread to the liver and is associated with the elevated serum levels of serum levels of glutamic oxaloacetic transaminase (SGOT) and glutamic pyruvic transaminase (SGPT).

In a study conducted in Turkey, there was an increase in the serum levels of SGPT $6.8 \%$ and SGOT $11.9 \%$ in the non-rotavirus subjects [1]. The incidence of the diarrhea due to rotavirus worldwide is 114 million children [2]. Research conducted in six hospitals in Indonesia found that $60 \%$ of pediatric diarrhea patients studied were caused by rotavirus [3]. Especially at Sanglah General Hospital in $2006,61 \%$ of the children under 5 years who suffered from diarrhea found having positive results of rotavirus.

Rotavirus infection in children mostly occurs in the intratestinal, but can also occur in the extraintestinal or systemic infection. Rotavirus can cause systemic infections such as hepatitis, nephritis, pneumonia, exanthema, disseminated intravascular coagulation, hemophagocytic lymphohistiocytosis, encephalitis, 
and cerebellitis. Another research found that as many as 600 thousand children in the world died from rotavirus and among fatal cases, there was an increase in liver enzymes [4].

Another research on transaminase enzyme levels in diarrhea patients found that an increase in SGPT serum levels of $8.5 \%$ and SGOT $24.4 \%$ in patients with diarrhea due to rotavirus infection, this result was significantly increased compared to diarrhea due to norovirus and adenovirus infection [5]. This spreading was influenced by the severity of the diarrhea that occurred in children. Diarrhea due to rotavirus with a severe degree of severity indicates that the rotavirus infection process is still ongoing and increases the possibility of the viremia process and virus is spreading to other organs through the lymphatic system, one of which is to the liver [6].

In the patients who had severe diarrhea, it was found that the differences of SGOT and SGPT serum levels in rotavirus and non- rotavirus diarrhea increased, respectively (SGPT 18.1\%, 5.6\%; SGOT 24.8\%, 14\%) [1]. Data on SGOT and glutamic pyruvic transaminase (SGPT) as the markers of the virus spreading process to the liver in the acute rotavirus and non-rotavirus diarrhea are still not available in Indonesia until now. Thus, research is needed to determine differences in transaminase enzyme levels in children with acute diarrhea due to rotavirus and non-rotavirus in the liver.

\section{Material and Methods}

\section{Study population}

The research samples were the children who looked for treatments in all public health centers in Denpasar, Sanglah General Hospital, and Wangaya General Hospital from 2018 to 2021. There were 71 subjects who met the inclusion criteria. The samples were determined by consecutive sampling. The followings were included in the exclusion criteria: Hepatitis virus [7], Wilson's disease [8], toxic condition due to drugs (hepatotoxic) [9], hepatic shock [10], Duchene muscular dystrophy [11], tuberculosis [12], cytomegalovirus [13], HIV infection [14], malnutrition and obesity [15], celiac disease [16], and inflammatory bowel syndrome [17]. SGOT is examined according to International Federation of Clinical Chemistry (IFCC) with pyridoxal-5-phosphate, whereas SGPT is examined according to IFCC without pyridoxal-5phosphate. The normal level of SGOT and SGPT is based on reference range for adults and children with units of U/L [18].

\section{Statistical analysis and study design}

This research was an observational descriptive cross-sectional study. All of the statistical calculations used the Statistical Product and Service Solutions (SPSS) computer system software. Descriptive analysis aimed to describe the characteristics of the research subjects and the variables studied.

Variables with numerical data scale will be displayed in the form of mean (SB) or median with minimum and maximum values if the data were not normally distributed. Variables with categorical data scale will be displayed in the form of relative frequency (amount and percent). The results of the descriptive analysis were presented using a single distribution table. All of the research variables with numerical scale were tested for data normality using the KolmogorovSmirnov test.

The data distribution that was not normal was displayed in the form of median or the data transformation was carried out. The distribution of data was said to be normal if the test result find $p>0.05$. The analysis used the Mann-Whitney U-test because the data normality test was not normal. The level of significance was expressed by $p<0.05$.

\section{Results}

During the research period from July 2019 to March 2021, there were 71 subjects who met the inclusion criteria, one subject was excluded because of stepping down so that a total of 70 subjects were obtained. The research subjects included outpatients and inpatients who experienced diarrhea in all Public Health Centers in Denpasar, Wangaya General Hospital, and Sanglah General Hospital.

The characteristics of the 70 research subjects had a median age of 16 months (minimummaximum, 6-56 months). Most of the research subjects were male $(70.0 \%)$ with the median of SGOT was 35 (11-261) and SGPT 21 (5-217), while in females, the median of SGOT was 45 (15-166) and SGPT 19 (14-94). The nutritional status of the research subjects was mostly in normal nutritional status $(68.6 \%)$, with the median SGOT was 38.5 (14-166) and SGPT 19 (5-217).

The results of this research obtained 17 (24.3\%) subjects with rotavirus, with $64.7 \%$ was male with a mean age of $15.6 \pm 9.4$ months. As many as $94.1 \%$ of rotavirus subjects aged $<24$ months had the examination results obtained, median of SGOT is 40 (14-166) and SGOT 21 (7-217). In the rotavirus group, the serum levels of SGOT in $3(17.6 \%)$ subjects and SGPT in $6(35.2 \%)$ subjects increased above normal limits. In the non-rotavirus group, the 
SGOT serum levels in 7 (13.2\%) subjects and SGPT in $13(24.5 \%)$ subjects increased above normal. The general characteristics of the subjects are shown in Table 1.

Table 1: The characteristics of research subjects

\begin{tabular}{lll}
\hline Characteristics & \multicolumn{1}{l}{ Group } & \\
\cline { 3 - 3 } & $\begin{array}{l}\text { Rotavirus total }=17 \\
\text { subjects }\end{array}$ & $\begin{array}{l}\text { Non-rotavirus total }=53 \\
\text { subjects }\end{array}$ \\
\cline { 2 - 3 } $\begin{array}{l}\text { Sex, } \mathrm{n}(\%) \\
\quad \text { Male }\end{array}$ & $11(64.7)$ & $38(71.7)$ \\
$\quad \begin{array}{l}\text { Female } \\
\text { Age, } \mathrm{n}(\%)\end{array}$ & $6(35.3)$ & $15(28.3)$ \\
$\quad \leq 24$ months old & $16(94.1)$ & $37(69.8)$ \\
$\quad>24$ months old & $1(5.9)$ & $16(30.2)$ \\
Nutritional status, $\mathrm{n}(\%)$ & $3(17.6)$ & $13(24.5)$ \\
$\quad$ Malnutrition & $11(64.7)$ & $37(69.8)$ \\
$\quad$ Normal & $3(17.6)$ & $3(5.7)$ \\
$\quad$ Overweight & & \\
The severity of diarrhea, $\mathrm{n}(\%)$ & $3(17.6)$ & $14(26.4)$ \\
$\quad$ Mild & $9(52.9)$ & $23(43.4)$ \\
$\quad$ Moderate & $5(29.4)$ & $16(30.2)$ \\
$\quad$ Severe &
\end{tabular}

The severity of the diarrhea was based on the Vesikari severity clinical score system and it was found that most subjects had moderate severity $52.9 \%$ for rotavirus and $43.4 \%$ for non-rotavirus. Each group had almost the same severe degree of severity of $29.4 \%$ for rotavirus and $30.2 \%$ for non-rotavirus, with median SGOT was 47 (19-261) and SGPT 25 (7-217). The clinical features of rotavirus and non-rotavirus diarrhea are shown in Table 2.

Table 2: Clinical features of rotavirus and non-rotavirus diarrhea

\begin{tabular}{lll}
\hline Variables & $\begin{array}{l}\text { Rotavirus } \\
\text { total = 17 subjects }\end{array}$ & $\begin{array}{l}\text { Non-rotavirus } \\
\text { total = 53 subjects }\end{array}$ \\
\hline $\begin{array}{l}\text { Age (month), median (minimum-maximum) } \\
\text { Diarrhea duration (days), } \\
\text { median (minimum-maximum) }\end{array}$ & $\begin{array}{l}13(6-39) \\
17(6-56)\end{array}$ & $3(1-10)$ \\
$\begin{array}{l}\text { Diarrhea frequency per day, } \\
\text { median (minimum-maximum) }\end{array}$ & $5(3-15)$ & $4(3-15)$ \\
$\begin{array}{l}\text { Vomiting duration (days), } \\
\text { median (minimum-maximum) }\end{array}$ & $1(0-2)$ & $1(0-5)$ \\
$\begin{array}{l}\text { Vomiting frequency per day, } \\
\text { median (minimum-maximum) }\end{array}$ & $2(0-10)$ & $1(0-10)$ \\
$\begin{array}{l}\text { Axillary temperature }{ }^{\circ} \mathrm{C}, \\
\text { median (minimum-maximum) }\end{array}$ & $36.9(36.5-39.0)$ & $37(36.5-40.2)$ \\
$\begin{array}{l}\text { Dehydration, } \mathrm{n}(\%) \\
\quad \text { Mild }\end{array}$ & $10(58.8)$ & $35(66.0)$ \\
$\quad \begin{array}{l}\text { Moderate } \\
\quad \text { Severe }\end{array}$ & $6(35.3)$ & $15(28.3)$ \\
$\quad \begin{array}{l}\text { Type of therapy, } \mathrm{n}(\%) \\
\quad \text { Outpatient } \\
\text { Inpatient }\end{array}$ & $1(5.9)$ & $3(5.7)$ \\
$\quad$ & $9(52.9)$ & $22(41.5)$ \\
& $8(47.1)$ & $39(58.5)$ \\
\hline
\end{tabular}

The analysis results of SGOT and SGPT examinations on rotavirus and non-rotavirus infections found that there were no significant differences. The analysis results of the differences between the levels of SGOT and SGPT on rotavirus and non-rotavirus diarrhea infections are shown in Table 3.

Table 3: Analysis results of differences in SGOT and SGPT levels on rotavirus and non-rotavirus diarrhea infections

\begin{tabular}{|c|c|c|c|c|}
\hline \multirow[t]{2}{*}{ Variables } & \multicolumn{2}{|l|}{ SGOT levels } & \multicolumn{2}{|l|}{ SGPT levels } \\
\hline & $\begin{array}{l}\text { Median (Minimum- } \\
\text { Maximum) }\end{array}$ & $p$ value & $\begin{array}{l}\text { Median (Minimum- } \\
\text { Maximum) }\end{array}$ & $p$ value \\
\hline Rotavirus $(n=17)$ & $45(16-168)$ & $0.077^{\mathrm{a}}$ & $22(14-91)$ & $0.120^{\circ}$ \\
\hline Non-rotavirus $(n=53)$ & $32(11-261)$ & & $18(5-217)$ & \\
\hline
\end{tabular}

\section{Discussion}

Rotavirus is one of the most common causes of diarrhea in children, the incidence of diarrhea due to rotavirus worldwide is 114 million children [2]. Reports from Venezuela showed that rotavirus occurred in $21.3 \%$ of children under 5 years old [19], and in Indonesia, $60 \%$ of pediatric patients suffered from rotavirus diarrhea [3]. In addition, in the WHO global rotavirus monitoring, the median rotavirus data among 48 countries were $40 \%$ [20]. Our results were higher than the reported research from Venezuela, but still lower than the global number $24.3 \%$.

Akelma et al. found in their research that in the patients with rotavirus diarrhea, the mean age was 33.46 \pm 31.85 months, SGPT levels in $42(15.4 \%)$ subjects and SGOT in $69(25.4 \%)$ subjects were found increasing [1]. In the non-rotavirus diarrhea group, the levels of SGPT in $25(6.8 \%)$ subjects and SGOT in $44(11.9 \%)$ subjects were found to be elevated above normal [1]. In this research, it was found that the median age was $16(6-56)$ months and rotavirus was found to occur more in $16(94.1 \%)$ children <2 years old in most cases.

In this research, the serum levels of SGOT and SGPT increased above normal in rotavirus and non- rotavirus diarrhea group, respectively, SGOT 3 (17.6\%), 7 (13.2\%); SGPT 6 (35.2\%), and $13(24.5 \%)$. In our study, most of the research subjects were male $(70.0 \%)$ with the median of SGOT 35 (11-261) and SGPT 21 (5-217), while in females, the median was SGOT 45 (15-166) and SGPT 19 (14-94). The sexes were mostly male, with rotavirus and non-rotavirus diarrhea groups, respectively, $11(64.7 \%)$ and $38(71.7 \%)$ in males; $6(35.3 \%)$ and $15(28.3 \%)$ in females.

Our research was in agreement with Akelma et al. [1] which found that the higher sex in the rotavirus group was male $54.4 \%$ and non-rotavirus group $58.4 \%$. Another study found that $68.75 \%$ of the rotavirus group were male and $70.83 \%$ were under 2 years old [21]. In this research, there were no clinically significant differences between rotavirus and non-rotavirus diarrhea. The description of dehydration and the need for hospitalization in patients with rotavirus diarrhea were in accordance with the results of a research done by Kucuk et al., it was found that the need for hospitalization in rotavirus diarrhea patients was $50 \%$ with mild, moderate, and severe degrees of dehydration, respectively, $20.7 \%, 67.1 \%$, and $12.2 \%(p=0.390)$ [5].

In a research conducted by Kawashima et al., it was found that the serum levels of SGOT and SGPT were both above the upper normal limit (SGOT <38 $\mathrm{U} / \mathrm{L} ; \mathrm{SGPT}<44 \mathrm{U} / \mathrm{L})$ in 23 of 26 subjects $(88.5 \%)$, and three of 26 subjects (11.5\%) [4]. Another research in Monmouth Philadelphia 2007, among 92 children with rotavirus, 75 children were tested for serum transaminase and found that $15(20 \%)$ children had an 
increase in SGPT and SGOT, the average increase of SGPT was $56 \mathrm{U} / \mathrm{L}$ (range, 44-114 U/L L), and the mean increase in SGOT was $80 \mathrm{U} / \mathrm{L}$ (range, 57-126 U/L) [22].

In a research done by Kucuk et al., it was found that the increase in SGPT levels was $8.5 \%$, $4.0 \%$, and $2.3 \%$, while the increase in SGOT levels was $24.4 \%, 8.1 \%$, and $2.3 \%$ in patients with rotavirus, norovirus, and adenovirus [5]. Transaminase levels showed that SGPT and SGOT serum levels increased, respectively, to $67 \mathrm{U} / \mathrm{L}$ and $89 \mathrm{U} / \mathrm{L}$ [5]. The mean serum levels of SGPT and SGOT in the rotavirus group were significantly higher than in the norovirus and adenovirus groups (SGOT $43.56 \pm 13.74,36.4 \pm 9.24$, and $38.04 \pm 8.04, p<0.05$, SGPT $27.2 \pm 12.62,22.1 \pm 9.63$, and $19.2 \pm 8.73, p<0.05)[5]$.

In our study, the median differences between SGOT and SGPT levels were not significant in rotavirus and non-rotavirus diarrhea groups (SGOT 45 [16-168], 32 [11-261], p = 0.077); (SGPT 22 [14-91], 18 [5-217], $p=0.12)$.

This insignificantly different result of transaminase levels could be influenced by the ability of strain-specific rotavirus to infect liver cells (HepG2) which occurs in the process of extraintestinal spreading and affects changes in the transaminase enzyme. In a genetic-based study to determine the type of strain and identify the viral phenotype involved in extraintestinal spread to the liver, genome segment 7 encoding the non-structural protein NSP3 and genome segment 6 was found to be significantly associated with viral spread to the liver and affect changes in transaminase levels. So far, rotavirus has many variants with $32 \mathrm{G}$ genotypes, $47 \mathrm{P}$ genotypes, and genome sequences that affect the coding of non-structural proteins that can manifest in extraintestinal spreading and affect transaminase enzyme changes [6].

Further research is needed to determine the virus genotype in the approach of this SGOT and SGPT level differences. The median levels of SGOT and SGPT in the non rotavirus group were found to be lower than in the rotavirus group, but the difference was not statistically significant. In non-rotavirus subjects, this difference of SGOT and SGPT levels can be influenced by other factors including infections other than rotavirus such as bacteria, adenovirus, norovirus, bacteria, fungi, and other etiologies, which were not examined.

\section{Conclusion}

This study concluded that there is a higher median level of SGOT and SGPT in children with acute diarrhea due to rotavirus infection compared to non-rotavirus infection, although it is not statistically significant. Future research needs to consider performing rotavirus genotype testing and specific testing to diagnose disorders that affect liver function.

\section{Limitations}

This study has several weaknesses, including: The examination was limited to rotavirus infection only, but other causes of infection such as adenovirus, norovirus, bacteria, fungi, and other etiologies were not examined. Exclusion criteria for old patients were only based on interviews and medical record data, while for new patients only based on interviews and no examination was carried out to establish the diagnosis.

\section{References}

1. Akelma AZ, Kutukoglu I, Koksal T, Cizmech MN, Kanburoglu MK, Catal F, et al. Serum transaminase elevation in children with rotavirus gastroenteritis: Seven years' experience. Scand J Infect Dis. 2013;45(5):262-67. https://doi.org/10.3109/0036554 8.2012.740573

PMid:23151057

2. Glass RI, Parashar UD, Bresee JS, Turcious R, Fisher TK Widdowson MA, et al. Rotavirus vaccines: Current prospect and future challenges. Lancet. 2006;368(9532):323-32. https://doi. org/10.1016/s0140-6736(06)68815-6

PMid:16860702

3. Sunarto Y, Aman AT, Bakri A, Waluya H, Firmansyah A Kadim M, et al. Burden of severe rotavirus in Indonesia. J Infect Dis. 2006;200 Suppl 1:S188-94. https://doi.org/10.1086/605338 PMid:19821711

4. Kawashima $\mathrm{H}$, Ishii $\mathrm{C}$, loi $\mathrm{H}$, Nishimata $\mathrm{S}$ Kashiwagi $\mathrm{Y}$, Takekuma $\mathrm{K}$. Transaminase in rotavirus gastroenteritis. Pediatr Int. 2012;54(1):86-8. https://doi. org/10.1111/j.1442-200x.2011.03532.x

PMid:22136601

5. Kucuk O, Ugras M, Bicer S, Col D, Giray T, Erdag GC, et al. Hypertransaminasaemia in children with viral gastroenteritis. Infez Med. 2016;24(1):32-7.

PMid:27031894

6. Ramig RF. Pathogenesis of intestinal and systemic rotavirus infection. J Virol. 2004;78(19):10213-20. https://doi.org/10.1128/ jvi.78.19.10213-10220.2004 PMid:15367586

7. Karyana IP, Putra IG. Diare Akut. Dalam Pedoman Pelayanan Medis Kesehatan Anak. Denpasar: Bagian/SMF IImu Kesehatan Anak FK UNUD/RSUP Sanglah; 2011. https://doi.org/10.35790/ ecl.4.2.2016.14678

8. Kang KS. Abnormality on liver function test. Pediatr Gastroenterol Hepatol Nutr. 2013;16(4):225-32. https://doi. org/10.5223/pghn.2013.16.4.225 PMid:24511518

9. Navarro VJ, Senior JR. Drug-related hepatotoxicity. N Engl J Med. 2006;354(7):731-9.

PMid:16481640

10. Soleimanpour $H$, Safari S, Rahmani $F$, Nejabatian A Alavian SM. Hepatic shock differential diagnosis and risk factors: A review Article. Hepat Mon. 2015;15(10):e27063. https://doi.org/10.5812/hepatmon.27063 
PMid:26587034

11. Zhu Y, Zhang H, Sun Y, Li Y, Deng L, Wen $X$, et al. Serum enzyme profiles differentiate five types of muscular dystrophy. Dis Markers. 2015;2015:543282. https://doi. org/10.1155/2015/543282

\section{PMid:26063958}

12. Kementrian Kesehatan Republik Indonesia. Profil Kesehatan Indonesia Tahun 2015. $1^{\text {st }}$ ed. Jakarta: Kementrian Kesehatan Republik Indonesia; 2016. https://doi.org/10.6066/ jtip.2013.24.2.121

13. Taylor GH. Cytomegalovirus. Am Fam Physician. 2003;67(3):519-24.

PMid: 12588074

14. Kementerian Kesehatan Republik Indonesia. Pedoman Tatalaksana Infeksi HIV dan Terapi Antiretroviral pada Anak di Indonesia. $1^{\text {st }}$ ed. Jakarta: Kementrian Kesehatan Republik Indonesia; 2014. https://doi.org/10.6066/jtip.2013.24.2.121

15. World Health Organization. Generic Protocol for Monitoring Impact of Rotavirus Vaccination on Gastroenteritis Disease Burden and Viral Strains. $1^{\text {st }}$ ed. Geneva: World Health Organization; 2008.

16. Anania C, de Luca E, de Castro G, Chiesa C, Pacifico L. Liver involvement in pediatric celiac disease. World J Gastroenterol. 2015;21(19):5813-22. https://doi.org/10.3748/wjg.v21.i19.5813 PMid:26019445
17. Urayama S, Chang EB. Mechanisms and treatment of diarrhea in inflammatory bowel diseases. Inflamm Bowel Dis. 1997;3(2):114-31. https://doi.org/10.1002/ibd.3780030207 PMid:23282752

18. Heil W, Ehrhardt V. Reference Range for Adults and Children Preanalytical Considerations. Switzerland: Roche Diagnostics $\mathrm{GmbH}$; 2008. p. 14-24.

19. Vizzi E, Pineros O, Gonzalez GG, Zambrano JL, Ludert JE, Liprandi F. Genotyping of human rotaviruses circulating among children with diarrhea in Valencia, Venezuela. J Med Virol. 2011;83(12):2225-32. https://doi.org/10.1002/jmv.22211 PMid:22012733

20. Greenberg HB, Estes MK. Rotaviruses: From pathogenesis to vaccination. Gastroenterology. 2009;136(6):1939-51. https:// doi.org/10.1053/j.gastro.2009.02.076

PMid: 19457420

21. Kargar M, Jafarpour T, Najafi A. Epidemiological survey of Group A rotaviruses infection among children under 5 years with acute diarrhea. Zahedan $\mathrm{J}$ Res Med Sci. 2012;14(8):43-7.

22. Teitelbaum JE, Daghistani R. Rotavirus causes hepatic transaminase elevation. Dig Dis Sci. 2007;52(12):3396-8. https://doi.org/10.1007/s10620-007-9743-2

PMid:17431773 